Linguistik Terapan 16 (1) (2019): 340-354

Jurnal Linguistik Terapan Pascasarjana

Available online

http://jurnal.unimed.ac.id/2019/index.php/JLT-Unimed

\title{
THE TRANSLATION STRATEGIES OF METAPHOR IN THE MAGIC OF THINKING BIG TRANSLATED INTO BAHASA INDONESIA BY DIAN PARAMESTI BAHAR
}

\author{
Khairani Hayat Situmorang \\ I.W. Dirgeyasa \\ Zainuddin
}

English Applied Linguistics Program

Postgraduate Program-Universitas Negeri Medan

Diterima Desember 2018; Disetujui Februari 2019; Dipublikasikan April 2019

\begin{abstract}
The research dealt with Metaphor Sentences. The aims of this study were: (1) to find out the translation strategies of metaphors are used in The Magic of Thinking Big and (2) to describe the translation strategies maintain metaphors in The Magic of Thinking Big. The research was conducted by using qualitative design. The data of this study were sentences. The data were collected through documentary technique and the instrument was the documentary sheet. The technique of data analysis was descriptive. The finding of this study revealed that: (1) The metaphor in The magic of Thinking Big were translated by applying six translation strategies, namely: word for word Translation (5.3\%) lieral translation (4.3\%), faithful translation (57.5\%), Free translation (3.2\%), communicative translation (30.5\%) and discursive creation was found (2.2\%). (2) The metaphors are maintained that found in the Magic of Thinking Big are original metaphors turned into another original metaphors, stock metaphors turned into another stock metaphors, adapted metaphors turned into adapted metaphors, dead metaphors turned into dead metaphors, original metaphor turned into stock metaphor, stock metaphor turned into original metaphor, meanwhile, 10 original metaphors and 1 dead metaphor are no longer classified as metaphors. Language has special characteristic that is metaphor sentences, therefore in the case of translating of metaphor sentences in which their concept in unknown for readers, the translator often faces the problems to find out the translation strategies to translate metaphor in a source language (SL) and how the metaphor sentences are maintained in the target language (TL).
\end{abstract}


How to Cite: Situmorang, Khairani Hayat (2019).

The Translation Strategies of Metaphor in the Magic of Thinking Big Translated into Bahasa Indonesia by Dian Paramesti Bahar. Jurnal Linguistik Terapan Pascasarjana Unimed, 16 (1): 340-354

${ }^{*}$ Corresponding author:

ISSN 0216-5139

E-mail:ranisitumorang8@gmai.com

\section{INTRODUCTION}

Literary translation is translation of literary works such as short stories,novels, poems, plays, and et cetera. It has special characteristics as literary worksdifferent from nonliterary works. According to Hodges (2011), it is a translationwhich not only need changing words from a language to another but also needs particular manners to express the texts in target language as sense which iscontained by source language text. Landers (2001) states that all facets of thework, ideally are reproduced in such a manner as to create in the TL reader thesame emotional and psychological effect experienced by the original SL reader.

Since translation has become increasingly important on both national and global level, it is definitely a subject worth a closer study. Obviously, there is a wide range of topics which could be investigated in terms of translational aspects. The present study focuses on the translation of one of the most fascinating and innovative aspects of language: metaphors.

Metaphor is considered by linguist as the most basic where one objects used to describe another object and both objects are essentially disparateentities, but common in one or more attributes (Encarta Dictionary). In otherwords, metaphor is use of a word or a phrase for the purpose of suggesting alikeness between the two.

In literature, metaphor as one of the stylistic elements does not merelyconvey ideas, in addition it also function as a tool for literally writers toembellish and give colors to their works. With the presence of the stylisticelements, including metaphor, writers always try to 
maximize it to reveal theiruniqueness. Concerning the semantic conventions, many violations are conspicuous in terms of using suchstyle of language. Metaphor is also usedwidely in philosophy, religion, politics, commerce, history and art.

\section{RESEARCH METHOD}

The research is conduct by using qualitative research. Bogdan and Bikklen (1992) explain that qualitative research is descriptive which mean what is going on and what data shows. Qualitative means to find out how a theory works in different fhenomena whose data collecteed are in the form of word rather than number.

In addition, this research is descriptive explanative, it means that is explains what are the translation strategies of metaphors that applied by the translator in The Magic of Thinking Big translated by Dian ParamestiBahar and findof the metaphors. Descriptive is the collection of the data to give explanation or description about the even accurancy of the report (Moleong,2006). By using this method the data will analyze, and the result of the research is the description of translation strategies of metaphors that applied the translator in the Magic of Thinking Big and the types of the metaphors.

\section{FINDINGS AND DISCUSSIONS}

Based on the data analysis, the findings of the study are formulated as the following:

1. Based nine translation strategies proposed by Newmark (1988), in this study, the dominant translation strategies was faithful translation. Meanwhile, semantic translation, adaptation, and free translation were not found. When the the translator applied the nine of translation strategies proposed by Newmark (1988), in other hand there were some metaphor sentences that were not able translated by applying those strategies. In keeping sense of language and the acceptable meaning and equivalence, the step could be done was applied another strategies, namely discursive creation. 
2. Based on the types of metaphor sentences by Newmark's (1988), from five types of metaphor, the types of metaphors were found : Dead metaphor, stock metaphor, original metaphor and adapted metaphor, recent metaphor were not found. Based the types metaphor that found in The Magic of Thinking Big, the dominant types metaphor was original metaphor. The metaphors are maintained that found in the Magic of Thinking Big are original metaphors turned into another original metaphors, stock metaphors turned into another stock metaphors, adapted metaphors turned into adapted metaphors, dead metaphors turned into dead metaphors, original metaphor turned into stock metaphor, stock metaphor turned into original metaphor, meanwhile, 10 original metaphors and 1 dead metaphor are no longer classified as metaphors.

Dealing with the research findings above, hence it is vitally important to match it theories to highlight whether these findings are contrastive or in line. These discussion to the translation strategies of metaphor sentences is forwarded. The researcher, then investigates the findings of translation strategies of metaphor sentences in The Magic of Thinking Big and the theories. Furthermore the investigation of wheather the findings are in line or contrastive to the relevant studies is also significant.

One of the most difficult problems in translating literary text is found in the differnces between cultures. People of given culture look at things from their own perspective. Gui (1995) agrees that translation is creative process for translation is not merely a transformation of an original text into a literal equivalent, but most succesfully convey the overall meaning of the original. Including that text's surrounding cultural significance; the process of searching out a target language cunterpart to a difficult source language word or phrase is often creative.

Motivation book is one of the texts that full cultural meaning. The magic of Thinking Big is recognized well as on of the best science fictive book ever. Science fictive book a 
genre of speculative fiction dealing with imaginative concepts such as futuristic science and technology that explores the potential consequences of scintific and other innovations.

Newmark (1988), the translation strategies are (1) word for word translation, (2) literal translation (3) faithful translation (4) semantic translation (5) adaption (6) free translation (7) idiomatic translation (8) communicative translation. in this research finding, it showed that the translation strategies of metaphor included are word for word translation, literal translation, faithful translation, semantic translation, adaption, free translation, idiomatic translation and communicative translation. Based on the analysis, the dominat translation strategy that applied in The Magic of Thinking Big was faithful translation. it ocured because there are many sentences in The Magic of Thinking Big produce the precise contextual meaning of the original within the constraints of the target language grammatical structure. Morever in this research, the reseach found another strategy that did not mention by the other researcher above. This procedure is not part of Newmark's (1988) procedures, but it was used by the translator when translating the metaphor sentences in The Magic of Thinking Big from english into indonesia. The strategy is discursive creation where in $2.2 \%$ of the data has been translated by applying this procedure (see table 4.1). Molina and Albir (2002) state that discursive creation is to establish a temporary equivalence that is totally unpredicatable out of context. From the analysis of the metaphor sentences in The Magic of Thinking Big it was apparent that the translator sometimes translated some metaphor sentences by applying discusive creation. This might be either because the SL metaphor sentences have no corresponding meaning in the TL. To make the transmitted message effective and convey the same impression in the SL even it was unpredicatable out of context, the researcher found that the translator applied a translation procedure discursive creation in The Magic of Thinking Big to perseve the message of the source text. 
There are many researches on translation strategies that maintained of metaphor sentences, particularly its usage in the novel. The numerous studies have described and raised many issues on the differen stratgeies in their way in translating the metaphor. In this research findings, it showed that the translation strategies of metaphor sentences that maintaining of metaphor sentences in The Magic of Thinking Big. The translation strategies that maitained of metaphor sentences include reproducing the same image in the target language, replacing the image in the source language with a standard target language image and converting a metaphor to its sense. The analysis determined that the most by preferred strategies used in maintained the metaphor sentences was reproducing the same image in the target language, the third translation strategies to maintained of metaphor proposed by Newmark (1988), reproducing the same image in the target language is the best way to translate stock metaphors, most frequently, and idioms. The translator has to depend on the strategy that maintained metaphor is reproducing the same image in the target language. as a way of maintaining metaphor in order to deliver a cultural messages, the translator mostly uses reproducing the same image in the target language since many metaphor sentences be easily broght to the TL metaphor. The translator choose this strategy rather than give some additional information of the metaphor sentences which are difficult to be acquainted since he considers the length of the story will effect the delivering of the message. In this way, the translator turns over in mind how The Magic of Thinking Big book that is read by holly ages can also be understood by the children considering their reading comprehension. However, in some very odd sentences, the translator should add some information so as to catch its metaphor messages. Yet by in large, the translation is acceptable. Applying this strategies was the highest among the relevan seven strategies by Newmark. It has been found $71.6 \%$ of the metaphor sentences were maintained by using this strategies (see table 4.2). Morever, this finding also corresponds with the findings of other researcher including: Retno Hendra 
(2013) who observed Kajian Terjemahan Metafora yang menunjukkan sikap dalam Buku Motivasi The Secret. The result of his finding was the translation strategies were dominantly Translated by literal translation. Alexander (2016) discussed The Translation Strategies of Metaphor in Dee's Supernova: The Knight, The princess, and Falling star. In his study, the translation strategies of metaphors in Dee's Supernova: The Knigt, The Princess, The Falling Star. That are the theories proposed by Newmark, Larson, and Nida. The design of the research of the study with qualitative approach. The researcher found, 7 literal translations, 17 faithful translations and 3 semantic translations, it means there are 27 of them employ imitative translations. it means that the translator mostly used imitative translations strategy. There was a total of only 30 translations since 1 metaphorical expression was not translated. The result of the second problem showed that majority of the metaphors, which refered to 27 expressions, managed to maintain their metaphorical expressions in the target text. Meanwhile, the other 4 were no longer classified as metaphors since they did not satisfy the requirements anymore.

In this resaerch, translating metaphor by smile plus sense, deleting and combining were not found. It s contrast to newmark's theory that proposed reproducing the same image in the target language, replacing the image in the source language with a standard target language image and converting a metaphor to its sense as part of translation strategies that maintain the metaphor sentences. It happen because firstly about translating metaphor by smile plus sense, there were no meaning of metaphor sentences maintained in several sentences. According to Newmark (2001), in this strategy, it has the advantage of combining communicative and semantic translation in addressing itself both to the layman and the expert if there is a risk that the simple transfer of the metaphor will not be understood by most reaaders, example transfer of image, example, he is as sharp and cunning as a fox, it means that some metaphors are incomplete without the addition of sense component. Secondy about 
deleting, there were no meaning of metaphor sentences that maintained by deleting strategies. Newmark (2001) states that this strategies is the nature can be only after the translator has wighed up what the mistakes what thinks more important and what less important in the text in relation to its intention. Thirdly about combining, there were no meaning of metaphor senteces that maintain by combining translation strategies, according Newmark (2001), the translator who transfer an image may wish to ensure that will be understood by adding a gloss.

Morever, in this research, the research faound the nonmaintained metaphor sentences, There are 11 data which are not classified as metaphor anymore. The data that categorized as maintained metaphor when they satisfy the requirements of a metaphor in term of form or meaning, which are based on newmark's theory on metaphor and the metaphor sentence translated that used the translation strategies that maintained of metaphor sentences, in order to, the metaphor sentences classified as maintained metaphor.The majority of the metaphors are maintained in the target text. The majority refers to 55 original metaphors turned into another original metaphors, 13 stock or cliche metaphors turned into another stock or cliche metaphors, 1 stock or cliche metaphor turned into another stock or cliche metaphor, 1 original metaphor turned a stock or cliche metaphor, 3 adapted metaphors turned into another origunal metaphors, and 11 dead metaphors turned into another dead mmetaphors. It means, out of 95 metaphors, 84 of them are maintained by the metaphor translation procedures. Meanwhile, the 11 other reamaining metaphors are no longer classified as metaphor, which all of them are original metaphors. They, exclude the omitted metaphors, have been pharaphrased which make them lose their comparison future, whic is the criteria of being classified as metaphor. To see the relevance between the first and the second problem, the connection between them is establish by looking at the metaphor translation procedures. Out of 3 of metaphors which are using literal transaltion apply Reproducing the same image in the TL and Translating 
metaphor by simile, 56 of metaphors which using faithful translation apply Reproducing the same image in the TL, replacing the image in the SL with a standard TL image, Converting a metaphor to its sense and two of them are non maintained metaphors, 2 of metaphors which using semantic translation apply Reproducing the same image in the TL and replacing the image in the SL with a standard TL image, 29 of metaphors which using communicative translation apply Reproducing the same image in the TL, replacing the image in the SL with a standard TL image, Translating metaphor by simile, Converting a metaphor to its sense. This result show that it is a priority to reproduce the same object and image in the target text, but in times when it is not done, the least that will do is to maintain the sense. In conclusion the key in translating metaphor, both by using general translation strategies and specific metaphor translation procedures are the sense of the metaphor. The sentence is not maintained by translation strategies that maintain of metaphor sentences by Newmark's (1988). From the analysis of the metaphor sentences in The Magic of Thinking Big it was apparent that the translator sometimes translated of metaphor sentences, but not maintained the metaphor sentences.

\section{FINDINGS AND DISCUSSIONS}

There were 8 translation strategies according to Peter Newmark (1988). But in this research, the researcher just found 5 translation strategies that were used by Dian Paramesti Bahar and she found another strategies that did not included in Newmark's theory namaely Discursive creation.

Table 1 The Translation Strategies of Metaphor Sentences in The Magic of Thinking Big Translated into Bahasa Indonesia

\section{Occurance}

\section{Translation Strategies}

Percentage


1. Word for Word Translation

2. Literal Translation

3. Faithful Translation

4. Semantic Translation

5. Adaptation

6. Free Translation

7. Idiomatic Translation

8. Communicative Translation

9. Discursive Creation

\section{5}

4

55

0

0

0

24

29

2

\section{3}

4.3

57.8

0

0

0

20

30.5

2.2

\begin{tabular}{lll}
\hline Total & 95 & 100
\end{tabular}

From the table 4.1 , it could be seen that the translation strategies used in The Magic of Thinking Big by translator, there were 8 strategies found of Imitative translation namely: word for word Translation (5.3\%) literal translation (4.3\%), faithful translation $(57.5 \%)$, and functional communication namely: Free translation $(3.2 \%)$, communicative translation (30.5\%). Meanwhile word for word translation, adaptation, Idiomatic translation were not found. As a new strategies namely discursive creation was found (2.2\%). 
Table 5. 2 The Translation Strategies That Maintained of Metaphors Sentences in The Magic of Thinking Big Translated into Bahasa Indonesia

Translation Strategies

1. Reproducing the same image in the TL

2. Replacing the image in the SL with a standard TL image

3. Translating metaphor by simile

4. Translating metaphor by simile + sense

5. Converting a metaphor to its sense

6. Deleting

7. Combining

\section{Occurance}

F Percentage

68 71.6

9

3

$0 \quad 0$

$14 \quad 14.8$

$0 \quad 0$

$0 \quad 0$

\section{Total} 95 100

From the table 4.3, it could be seen that the translation strategies that used in The Magic of Thinking Big by translator, there were 4 strategies found namely: Reproducing the same image in the TL (71.6\%), replacing the image in the SL with a standard TL image (9.5\%), Translating metaphor by simile (3.2\%), Converting a metaphor to its sense (14.8\%). Meanwhile Translating metaphor by simile + sense, Deleting, and combining were not found in The Magic of Thinking Big. Among 95, there are 84 translations which manage to maintain the metaphors and 11 data which do not. The data from source texts are compared to the target texts in order to see whether the data in the target text still preserve metaphors or not. When the target texts data still preserve metaphors, each of them are analyzed to determine whether the type of metaphor they preserve is the same as in the source text. Besides, the 
metaphor translation procedure is also taken into account to see how exactly the metaphor is preserved or is not.

The data are categorized as maintained metaphor when they satisfy the requirements of a metaphor in term of form or meaning, which are based on newmark's theory on metaphor. There are 84 data which the maintain metaphors. Those data could be categorized into six: original metaphor into original metaphor, stock metaphor into stock metaphor, adapted metaphor into adapted metaphor, dead metaphor into dead metaphor, stock metaphor into original metaphor, original metaphor into stock metaphor.

\section{CONCLUSIONS}

Having analyzed the data, conclusion of this study are drawn as the following:

1) The metaphor in The magic of Thinking Big were translated by applying six translation strategies, namely: word for word Translation (5.3\%) lieral translation (4.3\%), faithful translation (57.5\%), Free translation (3.2\%), communicative translation (30.5\%) and discursive creation was found (2.2\%).

2) The metaphors are maintained that found in the Magic of Thinking Big are original metaphors turned into another original metaphors, stock metaphors turned into another stock metaphors, adapted metaphors turned into adapted metaphors, dead metaphors turned into dead metaphors, original metaphor turned into stock metaphor, stock metaphor turned into original metaphor, meanwhile, 10 original metaphors and 1 dead metaphor are no longer classified as metaphors. 


\section{REFERENCES}

Bahar, Dian Paramesti . (2013). The Magic of Thinking Big;Jakarta: P.T Gramedia.

Schwartz, David . (1959). The Magic of Thinking Big; New York: NY 10020.

Newmark, P. (1981). Approaches to Translation. London: Oxford Press.

Newmark, P . (1988). A Textbook of Translation. London: Prentice Hall.

Nida, E. (1964). Toward a science of translating, E.J. Brill, Leiden.

Nida E. and Taber, C. (1969). The Theory and Practice Translation. Leiden: E.J Brill.

Munday, J. (2001). Introducing Translation Studies; Theories and Application. New York: Routledge.

Retno, H. (2013). Terjemahan Metafora yang menunjukkan sikap dalam Buku Motivasi The Secret . Retrieved from repo.iain-tulungagung.ac.id/2800 (December 2016).

Bassnett, S. (1991). Translation Studies. London: Routledge

Bogdan, R.C., and Biklen, S.K. (1992). Qualitative Research for Education. $\quad$ Boston: Allyn and Bacon

Catford, J.C. (1965) A Linguistic Theory of Translation, London: Oxford University Press.

Crystal, D. (1971). Linguistics. Harmondsworth: Pinguin.

Denzin, N. (1970) The Research Act in Sociology, Chicago: Aldine.

Emmit, M. and Pollock, J. (1997). Language and Learning: An Introduction for Teaching 2nd Language. Melbourne: Oxford University Press.

Hodges, P. July (2011). A Snapshot of Literary Translation and its Practitioners.

House, J (1977) A Model for Translation Quality Assessment, Tübingen: Gunter Narr.

Landers, Clifford E. (2001) Literary Translation: A practical Guide, New Jersey University Press: Multilingual Maters.

Larson, Mildred, L. (1984) Meaning-Based Translation: A Guide to CrossEquivalence. Lanham and New York: University Press of America.

Linclon, Y.S. and Guba, E.G (1985). Naturalistic Inquiry, California : Sage.

Lotman, J. Uspensky, B. (1978). “on the Semiotic Mechanism of Culture,” New Literary History, pp. 211-32. 
McKay, S. (2002). Teaching English as an International Language. Oxford: $\quad$ Oxford University Press.

Miles, M.B.,and Huberman, A.M (1984). Qualitative Data Analysis: A sourcebook of New Method. Beverly Hills. Sage.

Moleong, J.L. (2006). Methodology Penelitian Kualitatif; Edisi Revisi. Bandung: PT. Remaja Rosdakarya.

Nababan, M.R. (2001). Penelitian Penerjemahan: Apa dan Bagaimana. Solo: $\quad$ Pustaka Pelajar.

Santi, D.D.A. (2014) Translation Techniques and Equivalence in Indonesian Translation of Asean Charter. Retrieved from eprints.dinus.ac.id/ (January 2016)

Sapir, E. (1956). Course in General Linguistics. (R. Harris, trans.). London: Gerald Duckworth.

Toury, G. (1978), revised (1995). The Nature and Role of Norms in Translation. In Venuti, L. The Translation Studies Reader. London: Routledge.

Venuti, L. (1995). The Translator Invisibility: A History of Translation. London \& Newyork: Routledge.

Molina, L \& Albir. A.H. 2002. "Translation Technique and Revisited: A Dynamic and Functionalist Approach", in Meta: Translator"s Journal. XLVII, 4.

Bell, Roger T. 1991. Translation and Translating: Theory and Practice. New York: Longman

Ismail, O. (2012).A cognitive approach to the translation of creative metaphor in Othello and Macbeth from English into Arabic (PhD Thesis, Durham University/Faculty of English Language Center, 2012).

Jafari,O. (2013). Strategies of translating metaphors in foreign movies employed by Iranian subtitlers.(M.A Thesis, AllamehTabatabaie University/Faculty of Literature and Foreign Languages, 2013).

Nour, S. (2014).The translation of metaphor from Arabic to English in selected poems of Mahmoud Darwish with a focus on linguistic issues ( $\mathrm{PhD}$ Thesis, Leeds University/Faculty of English School, 2014).

Youssefi, K. (2009). An analysis of translation metaphor in Hafez's selected poems.(PhD Thesis, Sainas University, Malysia, 2009).

Al-Hasnawi, A. R. (2007). Acognitive approach to translating metaphor. Retrived July 3, 2007, from http://translationjournal.net/journal/41metaphor.htm. 
Alexander, K.(2016).The translation strategies of metaphors in Dee's supernova: the knight, the princess, and the falling star (thesis, sanata darma university, Yogyakarta,2016).

Yopy, T. (2015).translation techniques of simile in the novel angels \& demons to malaikat \& iblis.(Journal of Translation Techniques of Simile, Lecturer of Saleh University,2015) 